\title{
Legitimizacija imaginarnog i subverzija povijesnog u romanesknom diskursu Dževada Karahasana, Milorada Pavića i Jasne Horvat
}

\author{
Andrijana Kos-Lajtman \\ Učiteljski fakultet Sveučilišta u Zagrebu, Odsjek u Čakovcu, \\ Ante Starčevića 55, HR-40000 Čakovec, \\ andrijana.kos@ck.t-com.hr
}

\begin{abstract}
$\mathrm{Z}$ analizo ključnih romanov treh književnikov različnih nacionalnokulturnih bivališč (bosanskohercegovskega književnika Dževada Karahasana /Vzhodni divan, 1989/, srbskega književnika Milorada Pavića /Hazarski slovar, 1984/ in hrvaške književnice Jasne Horvat /Az, 2009/) so predstavljene tematske in svetonazorske podobnosti, ki izražajo njihov romaneskni diskurz. Svetovnonazorsko trije avtorji izkazujejo afirmacijski odnos do fanatizma in imaginacije ter relativni odnos do zgodovinskega.
\end{abstract}

Through the analysis of the key novels by three authors from various national and cultural mentalities - a Bosnian and Herzegovinian writer Dževad Karahasan (Vzhodni divan, 1989), a Serbian writer Milorad Pavić (Hazarski slovar, 1984) and a Croatian writer Jasna Horvat $(A z, 2009)$ - thematic and worldview similarities expressed in their novelistic discourses are discussed. All three authorial practices are characterized by close worldview axes, which are primarily demonstrated in the affirmative attitude towards the phantasmagorical and the imaginary on the one hand and the relativizing attitude towards the historical (and historiographical) on the other hand.

Ključne besede: Vzhodni divan, Hazarski slovar, Az, imaginarno, zgodovina, interkulturnost

Key words: The Eastern Divan, Dictionary of the Khazars, Az, imaginary, history, interculturality 


\section{Tri romana i postmodernistički kontekst}

Posljednjih 30-ak godina većina europskih književnosti obilježena je postmodernističkim odlikama. U srpskoj književnosti takvu praksu ovjerava velik broj književnika, no osebujnošću i odjekom u izvannacionalnim sferama gotovo simbolički je potvrđuje pojava Hazarskog rečnika Milorada Pavića (1984) (Damjanov 2002), u stranoj kritici prozvanog prvim piscem 21. stoljeća (Pavić 1989: 306). Riječ je o romanu koji radikalno redefinira žanrovski skelet prezentirajući intenzivne intradiskurzivne odnose (usp. Biti 2000: 226). Legitimirajući se autoreferencijalno kao »roman leksikon u 100000 reči« (Pavić 1989: 3), roman svojom sintaktičkom substrukturom (Peleš 1999) sintetizira sve najčešće postmodernističke pripovjedne strategije: fragmentarnost, protuslovlja, permutacije, prekinuti slijed, slučajnost, kratak spoj (usp. Lodge 1988, Damjanov 2002, Hakalović 2010). Tekst je »razgranat, disperzivan, višeglasan, polimorfan i otvoren«, predočen kroz hibridnu narativnu varijantu fikcionalizacije historiografskog i znanstvenog diskursa vezanog uz temeljni motiv izgubljenog naroda (Hazari/Kazari ${ }^{1}$ ) te njegove obrade $u$ dokumentarnim pisanim izvorima kršćanske, islamske i židovske provenijencije. Svojom semantičkom substrukturom (usp. Peleš 1999) roman, međutim, narušava dominantnu postmodernističku orijentaciju odustajanja od diskursa okrenutih spoznaji (znanosti, filozofije, religije), temeljeći svoje interpretacije na izvorištima spomenutih velikih metanaracija. S druge strane, većina je povijesnih i religijskih interpretacija u romanu hipotetičkog karaktera, obilježena propitujućim i 'potkopavajućim' odnosom prema ovjerenom diskursu historiografije i drugih znanosti. Upravo to je točka u kojoj se ogleda temeljna srodnost Pavićeva romana s romanima Karahasana i Horvat.

Istočni diwan (1989) prvi je roman Dževada Karahasana, s izvrsnom recepcijom i izvan sfere autorova matičnog književno-nacionalnog prostora. Postmodernističku orijentaciju teksta potvrđuje složena romaneskna arhitektura temeljena na principu odražavanja dijela u cjelini - trodjelna struktura kodirana međusobnim suodnosima dijelova na principu različitih odraza (pri čemu se i svaka od tri romaneskne cjeline također sastoji od tri dijela), gdje se prva priča ogleda u drugoj, a obje u trećoj, ironizaciji prethodnih (Kazaz 2001). Kao i u Hazarskom rečniku radnja se veže uz srednjovjekovnu prošlost, u ovom slučaju, arapsko-perzijskog svijeta. S druge strane, stalno mjesto naracije jest spoznajno propitivanje čovjekovih mogućnosti uopće, izvan konkretnog povijesnog vremena. Tom odlikom, kao i dubinskim psihološkim oblikovanjem karaktera, tekst participira u modernističkom svjetonazoru koji ne skriva težnju za propitivanjima etičke i metafizičke dimenzije čovjeka i svijeta. Na razini forme, međutim, igrivost i udruživanje žanrovski i tradicionalno raznorodnih elemenata njegovo su najbitnije obilježje. Tako se fabularni tijek generira iz mo-

\footnotetext{
${ }^{1}$ Osim u citatima, ime Hazari u radu će se nadalje navoditi u hrvatskoj inačici, kao Kazari.
} 
dela zagonetke-odgonetke u čemu je moguće prepoznavati postmodernističku otvorenost ludizmu obilježenom odgonetanjem (kodova, postupaka, žanrova, i njihovih suodnosa). Zanimljivo je, međutim, da je detektivska odgonetaljka u sve tri priče dana u prizmi sukoba (totalitarnih) pozicija moći i stvarateljatragatelja, što je jedan od čestih modernističkih motiva. Kao i u Pavićevu romanu, i ovdje veliku ulogu imaju kulturološki, filozofijski i religijski koncepti etnički i povijesno kompleksnih prostora, kao i znanstveno-teorijski diskurs, pri čemu se poseban tretman pridaje jeziku/pismu. Kod Pavića potonje se realizira iskorištavanjem performativne forme i funkcije rječnika/leksikona koja predstavlja matricu za raspodjelu priča, a kod Karahasana viševrsnim književnim iscrpljenjem naslovnog pojma diwan, ${ }^{2}$ ali i $a d a b,{ }^{3} \mathrm{u}$ širini njihove semantike, performacije i simbolike (usp. ibid.).

Treći roman jest $A z$ hrvatske književnice Jasne Horvat (2009). Roman je dobitnik književne nagrade HAZU za 2010. godinu, a stvaralačka igra i ludizam bitni su principi svih njegovih razina. I temeljna priča o Konstantinu Filozofu i njegovoj konstrukciji grafema glagoljičkog pisma obilježena je idejom Kreacije, što se osobito ogleda u prezentaciji konceptualizacije svakog glagoljičkog znaka te glagoljičkog sustava u cjelini. Roman slovno-brojevno-simbolički potencijal glagoljičkog pisma iskorištava na mnogim diskurzivnim razinama, pri čemu jedinstveno mjesto pripada semantici i simbolici što proizlaze iz koncepcije svakog pojedinog glagoljičkog znaka. U takvom postupku skloni smo prepoznavati novi tip hrvatskog postmodernističkog romana obilježenog igrivošću forme, ali semantičkim neodustajanjem od tradicionalnih spoznajnih sustava. U tome, kao i u povijesnoj tematici generiranoj iz subverzivnog, ali neposrednog odnosa prema historiografskom diskursu, $A z$ iskazuje veliku srodnost s romanima Pavića i Karahasana. To je još evidentnije promotri li se naglašena uloga koju u tekstu ima znanstveno-teorijski diskurs, kako historiografski tako i lingvistički - priči je na kraju dodan Slovarij (Azbukividnjak) kao metatekstualni pribor (usp. Virág 2007) za dekodiranje polivalentnosti cjelokupnog teksta.

\footnotetext{
${ }^{2}$ Mnogobrojna značenja riječi diwan jesu: vijeće, skupština, savjet, dvor, kuća, sofa, zbornik, zbirka tekstova, razgovor, besjeda, riječ.

${ }^{3}$ Protagonist prvog dijela romana Abdullah ibn al-Mukaffa iz 8. stoljeća smatra se prvim piscem adaba. Adab je izvedenica iz $d a^{\prime} b$, riječi koja se javlja u Kur'anu gdje znači zgoda, situacija, način života. Moguća značenja: put, staza, obučiti, odgojiti, ekvivalent europ. literatura, u klas. retorici točno određen žanr (onaj koji nije u stihu, kao ni bilo koji prozni spis koji je religijskog ili znanstvenog karaktera). Adab je i moralno usavršavanje ili predaja tradicije, književni oblik koji poučava ne zamarajući i obrazuje zabavljajući, beletrističko-didaktički žanr predviđen za obrazovanje adiba - intelektualca, čovjeka koji bi trebao biti upućen u cjelinu humanističkih znanja (usp. Karahasan 1994: 447).
} 


\section{Hazarski rečnik, Istočni diwan, Az: tematsko-svjetonazorne srodnosti}

\subsection{Alkemija imaginarnog}

Zajednička karakteristika triju romana jest duboko korespondiranje s razinama svijesti, percepcijama i doživljajnim sustavima kao što su snovi, vizije, halucinacije, ali i onim paraprostorima koje podrazumijevaju mitovi, legende, predaje. Pavić tako i historiografske i predajne činjenice često obrađuje na način da ih strukturira poput sna, jakim mateforizacijama iskaza potičući balansiranje između područja fantazmatičkog i noematičkog (Petzold 1986), kao i između vremenskih kategorija imanentnih svijetu kakav poznajemo - prošlosti, sadašnjosti i budućnosti. Zbog toga ćemo kod njega naići na fantazmatičke vremenoprostore kao što su poluprošlost i slično, determinirane samosvojnim logikama funkcioniranja, što potvrđuje i ulomak o dr. Muaviji:

A kako ga je u prošlosti opet sačekivala njegova struka, koje se isto tako gnušao kao $i$ svoje sadašnjice, zavlačio se u neku poluprošlost, gde su opal $i$ žad još polusestre i gde kukavica još broji koliko će dana čovek živeti, gde [...].

Jedne večeri, 1971. godine, kada je osećao svaki zub u glavi kao zasebno slovo, dr Muavija je seo i odgovorio na jedan oglas iz 1896. Pažljivo je ispisao ime i adresu neke ulice za koju nije znao da li još postoji u Aleksandriji i poslao ponudu poštom. Svake večeri otada odgovarao je na po jedan od oglasa s kraja XIX veka. Gomile njegovih pisama išle su u neizvesnost i jednog jutra došao je prvi odgovor. (Pavić 1989: 170-171)

Takvim postupcima karakterističnima za fantastičnu prozu, kao što su nevjerojatna zbivanja, pandeterminizmi, paralelne svjetotvorne konstelacije i sl., prošaran je cijeli Hazarski rečnik. Najveću ulogu imaju snovi; tematika snova izravno korespondira s temeljnom sadržajnom orijentacijom romana - pričom o Kazarima te, osobito, o njihovim svećenicima tzv. Lovcima na snove. Čitav je niz znakovitih iskaza koji potvrđuju jedinstven doživljaj svijeta kao alkemije sna i fantazmatičkog, a ovdje donosimo samo neke:

Jer, Hazari smatraju da se tokom četiri godišnja doba uvek smenjuju dve, a ne jedna godina, pri čemu jedna teče u suprotnom smeru od druge (kao i njihova glavna reka). Obe pri tome mešaju dane i godišnja doba kao karte, pa se otuda mešaju zimski s prolećnim i letnji s jesenjim danima. I ne samo to: jedna od dve hazarske godine teče iz budućnosti ka prošlosti, a druga iz prošlosti u budućnost. (Pavić 1989: 126)

U okviru ove problematike cijeli Istočni diwan moguće je tumačiti kao povijesni prikaz sukoba između ezoterijske kulture i njezina egzoterijskog okruženja, rezultat čega i jesu osobne drame protagonista kontekstualizirane metafizičkim dimenzijama (Kazaz 2001). Gotovo da je moguće reći da cijeli roman funkcionira na napetosti što proizlazi iz raskola između ezoterijskog i egzoterijskog tipa interpretacije proizvodeći stalnu svijest o supostojanju, ali i nepremostivosti dviju sfera, ljudske i metafizičke. Intertekstualna dimenzija romana uvelike pridonosi navedenom, osobito citiranjem Mukaffinih adaba, Tauhidijevih zapisa o Iskrenoj braći od Basre i sl. Legitimitet nevidljivih svjetova - pripadali oni religiji, filozofiji, ezoteriji, snovima ili predaji - konstantno 
podupiru Karahasanovi pripovjedači, barem do razine da postaju jednakovrijedni onim vidljivima. U nekim dionicama nalazimo i eksplicitno tumačenje, primjerice: »Savršeno naslikati ovaj, vidljivi svijet, znači pretočiti ga u neki od nevidljivih, a Bogu to nije drago jer On voli množinu svojih svjetova koji se međusobno odražavaju, sudaraju i mimoilaze. Da ih sve ne voli, ne bi stvarao tolike« (Karahasan 1994: 123-124). Ulomak koji možda najviše prezentira izokrenutu sliku stvarnosti, a da je pri tome automatski ne uranja u fantastično, jest ulomak o začudnoj slici, gdje se očima naslikane djevojčice pokušava odgonetnuti čin slikareva ubojstva:

Nisam odgovorio jer sam primijetio da oči na slici nisu prazne nego ispunjene nečim što ne pripada ljudskom oku. Prišao sam i sledio se - umjesto dužice i zjenice u oku su bili oni njegovi kvadrati, u bijeloj boji, koji se upisuju jedan u drugi i tako prave vrtlog. Nije to slijepo oko, to je oko koje se do beskonačnosti uvrće u sebe kao da želi zaokrenuti svoj pogled unutra i sagledati vlastitu unutrašnjost i moć da gleda. (Karahasan 1994: 111-112)

Misao o oku koje se do beskonačnosti uvrće u sebe, odražavajući višestruko odražen pogled u nedogled, pri tome ne iskazuje samo jedinstven doživljaj 'stvarnosti' priče kojoj pripada, već ujedno i autopoetički koncept Karahasanova romana, a gotovo da je moguće reći, i metatekstualni komentar ovog tipa postmodernističke prakse uopće ${ }^{4}$.

U romanu $A z$ prostori imaginarnog također su stalno mjesto svih pripovjednih cjelina. I nastanak glagoljičkog pisma prikazuje se kao Konstantinova stvaralačka vizija koju je doživio u osobitu raspoloženju »dok mu se tijelo grčilo pod vizijom« (Horvat 2009: 14). Njegov brat Metod, vrteći vodu u posudi i stvarajući vir, simulira pokus stvaranja svemira, opajajući se magijom riječi abrakadabra i slovno-brojevnom igrom koja se skriva u njoj (Horvat 2009: 48). Carica Teodora magijske običajne prakse prakticira kroz svakodnevicu - podvrgavajući se obredu skidanja uroka, pripremajući ljubavne čarolije za sina, pucketajući prstima ne bi li otjerala duhove, spravljajuću čudne zalogaje i napitke. Konstantin vidi Sofiju, imaginarnu ženu koja mu se obraća i potiče ga na plemenita djelovanja, okreće košulju na suprotnu stranu kako bi otjerao čežnju za domovinom, sanja čudesne snove kao što je onaj o trideset ptica što gledaju u lice Boga. Čak i svoju mršavost, Konstantin tumači snovima: »Mršav sam od snova, po cijelu noć trčim, zidam, gradim, ruke su mi pune posla... (Horvat 2009: 83).

Evidentno je da je zajednička sklonost sve tri romaneskne prakse iznimno olabavljenje granica između noematičkog i fantazmatičkog doživljaja svijeta. Spajajući istinonaličnu diskurzivnu prezentaciju povijesne zbilje s fantazmama karakterističnima za predaje, mitove, praznovjerja ili specifična pomaknuta

\footnotetext{
${ }^{4}$ Književnim interpretacijama (jedno)okularnosti kao temeljne problematike suvremenog svijeta skloni su i drugi modernistički, te osobito, postmodernistički autori. Jedan od najboljih primjera jest roman Kiklop (1965) hrvatskog književnika Ranka Marinkovića koji navedenom problematikom kodira čak i naslov romana.
} 
stanja svijesti kao što su halucinacije i snovi, sva tri romana unatoč iznimnoj težnji zahvaćanja u intelektualnu dimenziju spoznaje, istu istovremeno i potkopavaju, prezentirajući stalnu svijest o nemogućnosti jednodimenzionalnog dohvaćanja svijeta i čovjeka. Navedenu dvojnost možda najbolje ilustrira rečenica iz Begzadina pisma Al Mukaffi u Karahasanovu romanu: „Sjeti se kako lijepo kažeš da je čovjeku strašno na ovom svijetu baš zato što mu je dragi Bog naložio da zna, a ograničio mu znanje da se ne bi uznio preko svojih granica« (Karahasan 1994: 26).

\subsection{Relativnost povijesti}

Drugo bitno obilježje ovih romana jest smještanje zbivanja u povijesni, uglavnom srednjovjekovni kontekst. Izuzetak su pojedini fragmenti u Hazarskom rečniku, s referencijom u mlađim povijesnim razdobljima, te Intermezzo u Azu, autobiografski ulomak predisponiran suvremenim kontekstom. Ono što je još važnije od same srodnosti tematike jest način na koji joj se pripovjedački pristupa, u čemu također zapažamo podudaranje. Naime, iako sve tri romaneskne prakse pokazuju iznimnu upućenost u historiografske izvore, do mjere da se isti izravno inkorporiraju u priču, s druge strane prezentiraju snažnu svijest o njezinoj relativnosti i djelomičnosti. Potonje se očituje u stavu da ni jedan historiografski diskurs nije u stanju izreći sve o određenoj problematici, kao i da svaka spoznaja nužno ovisi o očištu promatranja. Relativnost povijesti predočava se stoga supostavljanjem, pa i kontrapunktiranjem različitih glasova i pogleda, prezentiranjem različitih izvora o istome, a povremeno i svjesnim nadograđivanjem elementima i strategijama fikcije ili čak fantastike. Hazarski rečnik prepun je takvih motiva i narativnih strategija, a nepostojanje jedne istine svjedoči već i jednakovrijednim tretmanom triju različitih izvorišta (kršćanskih, islamskih i židovskih) o istoj problematici. Određene leksikonske natuknice, predočene najčešće u formi priče, pojavljaju se čak po tri puta, uz veće ili manje razlike u izvedbi. Upravo takvom dvostrukom usmjerenošću diskursa Pavić postiže efekt 'oneobičenja': s jedne strane maksimalno naglašava historiografsku utemeljenost, dok je s druge relativizira već u uvodnom dijelu romana, strategijom mistificiranja kazarskog naroda:

\footnotetext{
Zna se takođe da su Hazari između dva mora osnovali moćno carstvo propovedajući nama danas nepoznatu veroispovest. [...] Hazari su se objavili istoriji ušavši u ratove s Arapima, i sklopivši savez sa vizantijskim carem Heraklijem 627. godine, ali je njihovo poreklo ostalo nepoznato, kao što su iščezli i svi tragovi koji bi govorili pod kojim imenom i narodom Hazare danas treba tražiti. Za njima je ostalo jedno groblje na Dunavu, za koje se ne zna je li zbilja hazarsko, i jedna gomila ključeva koji su umesto drške nosili srebrni ili zlatni trorogi perper, pa Daubmanus uzima da su ih lili Hazari. S istorijske pozornice Hazari su nestali zajedno sa svojom državom pošto se odigrala stvar o kojoj će ovdje biti najviše reći - pošto su preobraćeni iz svoje prvobitne vere u jednu (opet se ne zna koju) od tri poznate veroispovesti onoga i ovoga vremena - hebrejsku, islamsku ili hrišćansku. (Pavić 1989: 12)
} 
Najintenzivnija mistifikacija Kazara, ujedno temelj na koji se oslanja kriminalističko-fantastični fabularni krak što se razrješava u suvremenosti (slučaj ubojstva dr. Muavije), jest ponuđena interpretacija o neobičnoj sudbini prvog, Daubmanusova izdanja Rječnika iz 1691. Naime, prema predaji, između petsto primjeraka tog izdanja, otisnut je i jedan primjerak otrovnom bojom, zatvoren pozlaćenom bravicom, uz koji je išao i kontrolni primjerak sa srebrnom bravom. Nakon što je inkvizicija 1692. uništila sve primjerke, ostavljena su samo dva navedena primjerka. »Ko god bi otvorio knjigu ukočio bi se ubrzo, naboden na sopstveno srce kao na čiodu. Čitalac je naime umirao na devetoj stranici kod reči koje glase: Verbum caro factum est (Reč postade meso)« (Pavić 1989: 15). Za svoje izdanje Pavić kaže: »Izdavač ovog drugog izdanja Hazarskog rečnika potpuno je svestan da Daubmanusov materijal iz XVII veka nije pouzdan, da je legendaran u najvećoj mogućoj meri, da predstavlja nešto kao u snu ručak i drži se u mreži zabluda različite starine« (Pavić 1989: 18). Ovakvim određenjem, uz istodobno dokumentarističku prezentaciju izvora (preslika naslovnice prvobitnog Daubmanusova izdanja, vizualni prikazi materijalnih ostataka o kazarskom pitanju i sl.), roman očituje stalnu napetost između fiktivnog i faktivnog tipa diskursa koji se prelijevaju jedan u drugi posljedujući osebujnu recepcijsku intrigantnost.

Istočni diwan relativnost povijesti najviše iskazuje svojom strukturom gdje se postiže efekt odražavanja osobnih perspektiva jedne u drugoj. Roman ne projicira povijesne činjenice već sagledava čovjekove domete u okviru određenog društveno-kulturnog i svjetonazornog kompleksa. Relativnost povijesti prije svega se sagledava na pozadini (ne)relativnosti jezika/teksta, što se ogleda i u ponavljanjima određenih obrazaca između stvarnih povijesnih osoba i fiktivnih likova, u smislu da u romanu imaju potpuno jednakovrijedan književni tretman. Tako, primjerice, i Mukaffa, u prvom dijelu romana, nakon dužeg izbivanja od kuće zaboravlja sve ono što ne može dohvatiti tekstom, točnije, pismima koje prima od žene Begzade, primjerice, izgled njezina lica. Kroz cijeli roman tema zaborava/pamćenja provlači se na tri temeljne razine: općoj (zaborav povijesti), osobnoj (zaborav elemenata osobne priče) i jezičnoj (zaborav kao nemogućnost komunikacije). Ulomak gdje se i eksplicitno vidi udruživanje ovih razina jest onaj iz trećeg dijela romana, u dijelu razgovora između Sulejmana i emira:

Pogledaj ti nešto napisano. Vidiš jednu izuvijanu liniju, vidiš neke tačke i crtice, gledaš to i kao da unutrašnjim uhom čuješ glas koji ti govori te napisane riječi, recimo glas onoga koji je to zabilježio. Eto ti odmah zbrke: on je odsutan, glasa nigdje i riječi nigdje, a ti neki glas kao da čuješ i riječi su ti tu. /.... Pa onda pogledaj čime se ono bavi i o čemu piše, brate moj slatki. Neće on govoriti o tebi i o meni, o onima koje vidi i čuje, nego o nekim davnim ljudima ili čak o ljudima koji nikad nisu ni živjeli, ili će te podučavati šta brojevi mogu, ili će nešto mudrovati o džinima i njihovim navikama, iako nikad nije sreo niti vidio džina. I.... Oni iz nevidljivog svijeta dovlače ovamo neke odsutne ljude, kao što ti, na primjer, kad čitaš iz odsutnosti dovlačiš njihov glas i recimo njih, cijele. (Karahasan 1994: 418)

Srodan odnos prema historiografskim činjenicama možemo pratiti i $A z u$. Priča je smještena u povijesni kontekst, a roman otvara Hamvasov citat iz $\mathrm{Kr}$ - 
šćanstva i predaje što upućuje na njegovu važnost: »Nemoguće je bez predaje spoznati zbilju koja dira u temelje ljudskog života« (Horvat 2009: 5). Autoričina upućenost $\mathrm{u}$ pisane izvore o Konstantinu Filozofu i društvenom kontekstu njegova doba povlašteno je mjesto u strukturaciji diskursa i evidentna je kroz cijeli roman ekspliciranjem svih referenci gotovo znanstvenom metodologijom. S druge strane, kao i Pavić i Karahasan, i Horvat podvlači 'multiokularnost' povijesti na način da glavni lik, Konstantin Ćiril, biva osvijetljen iz četiriju različitih vidokruga, različitim dioptrijama, ali i metodologijama bilježenja. U prvom dijelu predočen je kroz subjektivan dnevnički diskurs brata mu Metoda, cjeloživotnog suputnika, u drugom dijelu iz perspektive bizantske carice Teodore s kojom se družio i prijateljevao, u trećem dijelu kroz kroničarske zapise Anastazija Knjižničara, jednog od autora Konstantinova životopisa nazvanog Kersonska (Italska) legenda, dok je u četvrtom dijelu romana pripovjedač hrvatski knez Mutimir, otac budućeg kralja Tomislava. Mozaičnost pristupa povijesti najviše se očituje u trećem, Anastazijevu dijelu, gdje se interpoliraju fragmenti osobnih Konstantinovih bilježaka koje Anastazije prevodi, Metodovi zapisi o dolasku u Hrvatsku, ulomci pisama Konstantinova učitelja Focija, ali isto tako i pisma biskupa Gaudericha upućena njemu, Anastaziju, kao suautoru Kersonske legende. Unatoč višestrukosti izvora i pogleda, odgovor o tome tko je bio Konstantin u konačnici ipak izmiče. Nepostojanje jedne istine i nesigurnost povijesti Horvat i dodatno ističe u sporednim motivima priče, uklapajući svoje autorske interpretacije na mjesta koja historiografija nije (još) popunila. Najbolji primjer jest motiv Gebalima, poznat iz rada Vladimira Mažuranića (1927). Koristeći ime Gebalim za sve Hrvate, ali i za konkretne povijesne osobnosti - Domagoja, Mutimira i Tomislava - autorica kroz pripovjedni glas i očište Anastazija, Mutimira i Ivana (Horvat 2009: 121) povijesnoj (kvazi)teoriji pristupa kao neprijepornoj činjenici, izdvajajući je iz njezina mitom obavijena konteksta i ugrađujući je u priču kao relevantnu historiografsku strukturu. Navedeno je osobito vidljivo u fiktivnom motivu pisma kazarskog vladara Kagana Gebalimu, što ga Konstantin prenosi Hrvatskom. Ne samo da kroz epizodu Konstantinova boravka među Kazarima Horvat također, na vlastiti način, dotiče temu koja je Paviću okosnica romana već kroz nenametljivo provučenu ideju o Hrvatima kao mogućem biblijskom narodu, iznosi novu, osebujnu interpretaciju tog nedovoljno rasvijetljenog narodnog imena:

Na Velebitu je doznao, Hrvati su riječ gebim izmijenili u dvije riječi-hara i hora. Osim gore, Gebalim je za njih značio prijatelja, ali i vladara svim Hrvatima. Vjerovali su da baš od gore potječe ime Hrvat ... Nadmetali su se u čitanju Biblije i poglavlja u kojima im se ime spominjalo: Iz 10,29; Iz 10,31; Ez 27,9; Ps 93,85. (Horvat 2009: 144)

U takvu pristupu povijesti, spajanjem potvrđenog i nepotvrđenog, znanstvenog i književnog, autorica romanu $A z$ pridaje dimenziju koja je rezultanta prethodno iznesenih parova. Takav stav prema povijesnom upravo korespondira

\footnotetext{
${ }^{5}$ Ovdje se, čini se, radi o greški, s obzirom da se narod Gebal spominje u psalmu 83,8, a ne 93,8 .
} 
S onim što nalazimo kod Pavića a što je koncentrirano u paraboličnu priču o kazarskom poslaniku, čovjeku koji je na svojim leđima imao ispisanu cijelu hazarsku povijest, a koji je umro jer ga vlastita koža ispisana poviješću počela strahovito svrbjeti: »Taj je svrab bio nepodnošljiv i on je preminuo s olakšanjem i srećan što će najzad biti čist od istorije« (Pavić 1989: 72). Svijest o neotklonjivosti i egzistencijalnoj važnosti povijesti, uz istodobno uviđanje njezine nedorečenosti, hermetičnosti, pa i pogubnosti, zajedničko je svojstvo Pavića, Karahasana i Horvat te jedna od temeljnih aporija njihovih tekstualnih praksi.

\subsection{Međukulturni dijalog - komunikacija identiteta}

Sve tri romaneskne prakse kronotopiraju svoje radnje u prostore izrazitih međukulturnih dodira. Bitni motivi koji grade priče, kao i fragmenti nefabularnog diskursa, u sva tri romana odnose se na različite etničke, religijske, filozofijske, umjetničke, znanstvene i društvene utjecaje te već i sami po sebi predstavljaju poticaj za promišljanje široke lepeze sličnosti i razlika među kulturama. Pavić fokusira pogled na nestali narod, Kazare, ali temu paralelno prelama kroz tri različite dioptrije označene religijskim predznakom, ne osiguravajući ni jednoj prvenstvo. Karahasan prikazuje arapsko-perzijski svijet, a Horvat ponovno prostore bliske onima u Pavićevu romanu: Balkan, Carigrad, Rim, ali i prostor velebitske Hrvatske. Autori se svjesno odlučuju za prostore koji su stoljećima poprišta burnih događanja i intenzivnih međukulturnih dijaloga. Orijentacija prema onome što je bitno obilježje vlastita kulturnog ili religijskog identiteta, a u javnom ili znanstvenom diskursu leži još uvijek nedovoljno rasvijetljeno, vidljiva je kod svih autora. Možda najviše kod Horvat, koja kao glavnu temu romana uzima prvo hrvatsko nacionalno pismo, odlučujući se već i naslovnim imenovanjem teksta za simboličku odrednicu $A z$, po imenu prvog glagoljičkog slova, koja jasno iskazuje ideološko-svjetonazornu potku: Ja, kršćanin (Horvat 2009: 11). Iako je takvu orijentaciju Konstantin širio diljem slavenskog svijeta te Horvat nacionalni habitus kojemu pripada vrlo autentično situira u širi kulturni kompleks, svijest o povijesti, jeziku, kulturi i religiji kao nezaobilaznim identitetnim narodnim odrednicama prilično je razvidna. Svjetlo na poziciju Hrvata u okviru kulturnog konglomerata koji roman prikazuje, Horvat baca već spomenutim motivom Gebalima, nudeći jednu od mogućih interpretacija geneze naroda i imena. Sličan kulturni konglomerat prikazuje i Pavić, usložnjen dodatno jednakovrijednim tretmanom triju različitih religijskih izvora, kao i mjestimičnim fantastičnim modusom prezentacije, analogno onome što se u okviru magičnog realizma ponekad određuje tzv. fantastičnim realizmom. Habitus srpskog nacionalnog prostora upisan je u tekst uglavnom kroz sporedne motive kao što je, primjerice, Čelarevo, arheološko nalazište sa srednjovjekovnim grobljem u blizini Novoga Sada. Zanimljiv je i motiv Konstantina Ćirila kojeg, iako u manjoj mjeri od Horvat, Pavić također višekratno dotiče. Fokusirajući se u prvom redu na njegovu ulogu u hazarskoj polemici Pavić ga svejedno predstavlja i kao pismotvorca, s primarnom orijentacijom (srodno 
nacionalno-prostornom habitusu iz kojega sam potječe) na ćirilicu a ne glagoljicu. U Karahasanovu romanu upis elemenata vlastitog društveno-kulturnog konteksta uglavnom se odvija na razini koja proizlazi iz religijskog identiteta, viševrsnim rasvjetljavanjem kulturnih slojeva islamskog svijeta.

\section{Zaključno: dvije tematsko-svjetonazorne dimenzije i treća kao njihova rezultanta}

Usporedbom analiziranih elemenata moguće je determinirati višestruku srodnost između triju romana na razini njihove semantičke, tj. tematsko-svjetonazorne substrukture. Izrazitih srodnosti moguće je pronaći i na strukturalnooblikovnoj razini romana, iako se njome u ovom radu nismo bavili, gdje i srpski, i bosanskohercegovački, i hrvatski roman ispoljavaju mnoge karakteristike formacije što se obično određuje postmodernističkom. Na semantičkoj razini, međutim, i Hazarski rečnik, i Istočni diwan i Az iskazuju orijentaciju netipičnu za postmodernizam - referencijalnu usmjerenost prema spoznajnim sustavima utemeljenima u tradiciji ljudske intelektualnosti, u prvom redu prema historiografiji, ali i prema drugim znanostima (osobito lingvistici) i prema religiji. Njihovo utjecanje takvim monumentalnim dijakronijskim sustavima, međutim, odvija se na način u kojemu je moguće očitavati sumnju, skepsu, pa i provokaciju, bitna obilježja svih avangardnih iskaza. Iako postmodernistički iskaz uglavnom ne projicira duhovnu klimu avangarde - što znači da najčešće nije ni prevratnički ni utopijski - u iskaznim modelima triju književnika moguće je očitavati odrednice navedenog. U takvu odnosu prema stvarnosti u navedenim romanesknim praksama, s jedne strane, očita je svijest o relativnosti svake spoznaje i istine, osobito povijesne, nužno posredovane medijatorima neodvojivima od subjektivnosti pogleda. Ono povijesno stoga se konstantno subverzira narativnim strategijama propitivanja povijesnih istina, ponudom alternativnih interpretacija ili višestrukih izvorišta, kako u samoj priči, tako i u metatekstualnom romanesknom priboru. Najvažnija strategija u navedenoj intenciji, međutim, jest ono što smo odredili drugom bitnom karakteristikom ovih diskursa - okretanje imaginarnom. Preplićući prezentaciju povijesne zbilje s načinima percepcije svijeta karakterističnima za predaje, mitove, vjerovanja, ali i halucinacije i snove, sva tri romana unatoč dubokom zadiranju $\mathrm{u}$ intelektualnu dimenziju spoznaje, istu istovremeno i potkopavaju. Rezultat navednog jest snažna svijest o nemogućnosti jednoznačnog dohvaćanja svijeta i čovjeka, što za posljedicu nužno ima subverziju onog povijesnog. Vidljivo je, dakle, da se radi o dvama međusobno povezanim procesima, o efektu tzv. spojenih posuda. Davanjem važnosti imaginarnom i fikcijskom subverzira se ono realno i fakcijsko, okretanjem potonjem, negira se prvo. Naracija stoga u sva tri primjera permanentno balansira između jednog i drugog pola, a rezultat takvih otklona, njihova svojevrsna sinteza, očituje se u trećoj bitnoj karakteristici navedenih južnoslavenskih romana. Naime, upravo u tematiziranju onoga što je odredilo narodnu svijest tijekom stoljeća, kao što su običajne prakse i 
vjerovanja s jedne strane, a pismenost i znanost s druge, ovi romani očituju težnju da se navedeni tradicijski dometi zabilježe i problematiziraju. Sva tri romana tako smještaju radnje u prostore višestrukih kulturnih povezanosti, u regije stoljećima obilježene dijalogom etnosa, kultura i religija, svjedočeći o plodnim sustavima interkulturalnih znakovnih veza i o neizbježnosti različitog doživljavanja istog. No, s druge strane, čini se da se upravo u činjenici da je riječ o prostorima međuetničkih dodira, te istodobno, o 'malim' narodima $\mathrm{i}$ jezicima kojima su i sami nužno autorski determinirani, krije uzrok njihova nepripadanja uobičajenim tijekovima postmodernističkih poetičkih praksi. I dok pojedini kritičari (prvenstveno govoreći o Paviću) takvo odmicanje nazivaju »trivijalnim čudovištima postmodernizma« (Hakalović 2010) jer se »trivijalizira ono što postmodernizam aktualizira i promovira kao 'slavljenje razlika' i antitotalitarizam u interpretaciji« (ibid.), ovdje ne samo da nismo skloni takvom sagledavanju, osobito stoga jer nam se čini da u tekstovima za njega nema nimalo argumenata, već pokušavamo doprijeti i do uzroka njihove netipične orijentacije. Naime, upravo u činjenici da sva tri autora pripadaju malim, još uvijek nedovoljno prepoznatim europskim kulturama, koje su tijekom povijesti prolazile faze svoje veće ili manje egzistencijalne ugroženosti, skloni smo tražiti uzroke njihova odmaka od postmodernističkih intencija karakterističnih za zapadna društva te težnju promicanja onih tema, motiva i svjetonazora upisanih u temeljne identitetne odrednice navedenih kulturnih habitusa.

\section{LITERATURA}

Božidar ALAJBEGOVIĆ, 2010: Imaginarno kao okosnica stvarnosti. Vijenac XVIII/ 432,8 .

Vladimir BITI, 2000: Pojmovnik suvremene književne i kulturne teorije. Zagreb: Matica hrvatska.

Sava DAMJANOV, 2002: Srpska postmoderna proza na kraju 20. veka. Polja. Časopis za književnost i teoriju XLVII/421, http://polja.eunet.rs/polja421/421-11.htm\#Top.

Anela HAKALOVIĆ, 2010: Trivijalna čudovišta postmodernizma. (Sic!). Časopis za po-etička istraživanja i djelovanja 3., http://www.sic.ba/rubrike/temat/anela-hakalovictrivijalna-cuda-postmodernizma/, 26.06.2010.

Jasna HORVAT, 2009: Az. Zagreb: Naklada Ljevak.

Dževad KARAHASAN, 1994: Istočni diwan. Klagenfurt/Celovec: Bosanska biblioteka.

Enver KAZAZ, 2001: Priča/tekst/svijet. Romani Dževada Karahasana. Novi izraz 3/12, http://www.openbook.ba/izraz/no12/12_enver_kazazl.htm.

Zoran KRAVAR, 2003: Antimodernizam. Zagreb: AGM.

David LODGE, 1988: Načini modernog pisanja. Zagreb: Globus. 
Jasmina LUKIĆ, 1992: Hazarski rečnik kao postmoderna heterotopija. Zbornik izlaganja sa devetih književnih susreta »Savremena srpska proza» 5. http://www.rastko.rs/ knjizevnost/pavic/index.html.

Vladimir MAŽURANIĆ, 1927: Gebalim. Posebni otisak Kola Matice hrvatske knj. VIII. iz god. 1927. 3-14.

Milorad PAVIĆ, 1989: Hazarski rečnik. Beograd: Prosveta.

Gajo PELEŠ, 1999: Tumačenje romana. Zagreb: Artresor.

Milivoj SOLAR, 2005: Retorika postmoderne. Zagreb: Matica hrvatska.

Zoltan VIRÁG, 2007: Odnosi i glasovi u tranziciji. Osijek: Matica hrvatska Ogranak Osijek.

\section{IMAGINACIJA IN ZGODOVINSKOST V ROMANESKNEM DISKURZU DŽEVADA KARAHASANA, MILORADA PAVIĆA IN JASNE HORVAT}

Dževad Karahasan (Vzhodni divan, 1989), Milorad Pavić (Hazarski slovar, 1984) in Jasna Horvat $(A z, 2009)$ so avtorji treh neznačilnih postmodernističnih romanov, ki imajo po zunanji zgradbi trden koncept, njihova notranja zgradba pa jih povezuje s tradicionalnimi sistemi kognitivne znanosti, filozofije in religije. Za vse tri avtorje je značilen afirmativni odnos do fantazmi in imaginacije ter relativni odnos do zgodovinskega - njuno povezovanje in prepletanje predstavlja tretjo pomembno tematsko in svetonazorsko razsežnost romanov, $\mathrm{tj}$. dosledno predstavljanje medetičnih in medkulturnih povezav različega etnosa in prostora; gre za pripovedni postopek, ki je upošteva svojo kulturno identiteto, ljudsko ustvarjalnost in intelekt nasploh. Najpomembnejšo vlogo pri povezovanju teh postopkovnih značilnosti ima pri vseh treh piscih jezik, ki omogoča, da se v romanih razvijajo neznačilni postmodernistični diskurzi, ki so usmerjeni v premišljeno oblikovanje forme in skrbijo za njeno igrivost, hkrati pa omogočajo tudi približevanje k mejam zaznavnega. Vzroki za odmik od postmodernističnih teženj, ki so značilne za zahodna družbe, so predvsem $v$ diahronem in sinhronem položaju naroda in književnosti, ki sta $\mathrm{v}$ prevladujočem evropskem prostoru skoraj neopazna in neprepoznavna, čeprav si prizadevata ohraniti svojo identiteto in si zagotoviti svoj prostor v evropski in svetovni književnosti. 